\title{
PENGARUH GAYA KEPEMIMPINAN DAN KEPUASAN KERJA TERHADAP MOTIVASI KERJA DAN DAMPAKNYA TERHADAP KINERJA KARYAWANDI BPJS KESEHATAN KANTOR CABANG LANGSA
}

\author{
Saviqa Intan Maulida Bakri \\ Universitas Islam Sumatera Utara \\ Saviqa.intan@gmail.com
}

\begin{abstract}
The purpose of this study was to obtain empirical evidence of: (1) Style leadership Motivation influential work in "BPJS Kesehatan"Langsa Branch office ; (2) Provision of job satisfaction influence the motivation to work in "BPJS Kesehatan" Langsa Branch office; (3) Style leadership Attainment of an effect on employees performance at "BPJS Kesehatan"Langsa Branch office; (4) Provision of Jab Satisfactioneffect the employees performance at "BPJS Kesehatan"Langsa Branch office; (5) Motivation of Achievement affect the employees performance at "BPJS Kesehatan"Langsa Branch Office. In connection with the research objectives, the population of this study is an employee / employees of "BPJS Kesehatan"Langsa Branch office. Total population employee / employees who actively work in "BPJS Kesehatan"Langsa Branch Officeis 47 people. Data analysis method withpath analysis. The results showed that: (1) Style leadership positive and significant impact on work motivation in "BPJS Kesehatan" Langsa Branch officeof 0.384 or 38,4\%; (2) Provision of Jab Satisfactionpositive and significant impact on work motivation in "BPJS Kesehatan" Langsa Branch officeof 0.584 or 58.4\%; (3) Style leadership positive and significant impact on the employees performancein "BPJS Kesehatan" Langsa Branch office of 0.235 or $23.5 \%$; (4) Provision of Jab Satisfaction positive and significant impact on the employees performancein "BPJS Kesehatan" Langsa Branch officeof 0.151 or $15.1 \%$; (5) work motivation is positive and significant effect on the achievement of employees performancein "BPJS Kesehatan" Langsa Branch office of 0.569 or $56.9 \%$.
\end{abstract}

Keywords : Style Leadership, Job Satisfaction, work motivation, Employees Performance

ABSTRAK : Tujuan penelitian ini adalah untuk mendapatkan bukti emperis tentang: (1) Gaya Kepemimpinan berpengaruh terhadan Motivasi kerja di Kantor BPJS Kesehatan Cabang Langsa; (2) Kepuasan Kerja berpengaruh terhadap motifasi kerja di Kantor BPJS Kesehatan Cabang Langsa; (3) Gaya Kepemimpinan berpengaruh terhadap Kinerja Karyawan di Kantor BPJS Kesehatan Cabang Langsa; (4)Kepuasan Kerja berpengaruh terhadap Kinerja Karyawan di Kantor BPJS Kesehatan Cabang Langsa; (5) Motivasi kerja berpengaruh terhadap Kinerja Karyawan di Kantor BPJS Kesehatan Cabang Langsa. Populasi dari penelitian ini adalah pegawai/karyawan Kantor BPJS Kesehatan Cabang Langsa. Jumlah populasi pegawai/karyawan yang aktif bekerja di Kantor BPJS Kesehatan Cabang Langsa adalah 47 orang. Metode analisis data dengan path analysis (analisis jalur). Hasil penelitian menunjukkan bahwa: (1) Gaya Kepemimpinan berpengaruh positif dan signifikan terhadap motivasi kerja di Kantor BPJS Kesehatan Cabang Langsa sebesar 0,384 atau 38,4\%; (2) Kepuasan Kerja berpengaruh positif dan signifikan terhadap motivasi kerja di Kantor BPJS Kesehatan Cabang Langsa sebesar 0,584 atau 58,4\%; (3) Gaya Kepemimpinan berpengaruh positif dan signifikan terhadap Kinerja Karyawan di Kantor BPJS Kesehatan Cabang Langsa sebesar 0,235 atau 23,5\%; (4) Kepuasan Kerja berpengaruh positif dan signifikan terhadap Kinerja Karyawan di Kantor BPJS Kesehatan Cabang Langsa sebesar 0,151 atau 15,1\%; (5) Motivasi kerja berpengaruh positif dan signifikan terhadap Kinerja Karyawan di Kantor BPJS Kesehatan Cabang Langsa sebesar 0,569atau 56,9\%.

Kata kunci : Gaya Kepemimpinan, Kepuasan Kerja, MotivasiKerja, Kinerja. 


\section{Pendahuluan}

Manajemen merupakan sebuah kegiatan, pelaksanaannya disebut managing dan orang yang melakukannya disebut manajer. Individu yang melakukan tugas keseluruhan tersebut bersifat manajerial yang terpenting dari tugas tersebut tidak dapat dilakukan seorang diri, tugas-tugas operasional dilakukan melalui kelompok anggotanya.Hal-hal yang dikerjakan seorang manajer harus jelas, yakni merupakan kegiatan yang dihimpun dari beberapa fungsi fundamental menjadi suatu proses yang unik.Menurut Hasibuan (2002: 1) mengemukakan bahwa: "Manajemen adalah ilmu dan seni yang mengatur proses pemanfaatan sumber daya manusia dan sumbersumber lainnya secara efektif dan efisien untuk mencapai suatu tujuan tertentu.

Berkaitan dengan manajemen, tidak terlepas dari kepemimpinan. Kepemimpinan menurut Robbins (2010:146) adalah apa yang dilakukan pemimpin. "Kepemimpinan merupakan proses memimpin sebuah kelompok danmempengaruhi kelompok itu dalam mencapai tujuannnya". Armstrong (2003) dalam (Sudarmanto, 2009: 133) menyatakan kepemimpinan adalah proses memberi inspirasi kepada semua karyawan agar bekerjasebaik-baiknya untuk mencapai hasil yang diharapkan.Kepemimpinan adalah cara mengajak karyawan agar bertindak benar, mencapai komitmen dan memotivasi mereka untuk mencapai tujuan bersama. Kepemimpinan menurut Anogara (2003:2) diartikan sebagai kemampuan seseorang untuk dapat mempengaruhi orang lain, melalui komunikasi baik secara langsung maupun tidak langsung dengan maksud untuk menggerakkan orang-orang tersebut agar dengan penuh pengertian, kesadaran dan senang hati bersedia mengikuti kehendak-kehendak pemimpin itu.Kepemimpinan menurut Dubrin (2005:3) adalah upaya mempengaruhi banyak orang melalui komunikasi untuk mencapai tujuan, cara mempengaruhi orang dengan petunjuk atau perintah, tindakan yang menyebabkan orang lain bertindak atau merespons dan menimbulkanperubahan positif, kekuatan dinamis penting yang memotivasi dan mengkoordinasikan organisasi dalam rangka mencapai tujuan, kemampuan untuk menciptakan rasa percaya diri dan dukungan diantara bawahan agar tujuan organisasional dapat tercapai. (Brahmasari \& Suprayetno, 2008: 126)
Menurut Robbins (2003;78) kepuasan kerja adalah "sikap umum terhadap pekerjaan seseorang yang menunjukkan perbedaan antara jumlah penghargaan yag diterima pekerja dan jumlah yang mereka yakini seharusnya mereka terima".Menurut Robbins \& Judge (2009 : 118), salah satu indikator berhasiltidaknya manajemen dalam hal sumber daya manusia adalah tingkat kepuasankerja karyawan. Luthans (2011: 141) menyatakan bahwa kepuasan kerjasebagai seperangkat peraturan yang menyangkut tentang perasaan menyenangkandan tidak menyenangkan berhubungan dengan pekerjaan mereka. Seorangkaryawan yang memperoleh kepuasan dalam bekerja tentunya aka berdampak terhadap kematangan psikologis yang pada gilirannya akan menimbulkan gairahdan semangat untuk bertindak mencapai kinerja yang lebih tinggi daripada orang yang tidak terpuaskan.

Motivasi menurut Hasibuan (2012:141) berasal dari kata latin "movere" yang artinya dorongan atau menggerakan. Motivasi merupakan suatu uraian yang mencakup berbagai aspek dalam tingkah laku manusia yang bervariasi. Motivasi dalam manajemen hanya ditunjukan pada sumber daya manusia pada umumnya dan bawahan pada khususnya. Masalah utama dalam motivasi adalah bagaimana caranya menggerakkan sumber daya manusia dan potensi karyawan agar mau bekerja sama secara optimal dan produktif, berhasil mewujudkan dan mencapai tujuan yang telah ditetapkan oleh perusahaan.Menurut Rivai (2010:837) menyatakan, motivasi adalah "serangkaian sikap dan nilai-nilai yang mempengaruhi individu untuk mencapai hal yang spesifik sesuai dengan tujuan individu".

Istilah kinerja berasal dari kata Job performance atau performance yang berarti prestasi kerja atau prestasi sesungguhnya yang dicapai oleh seseorang (Mangkunegara, 2008: 67). Biasanya orang yang kinerjanya tinggi disebut orang yang produktif dan sebaliknya orang yang tingkat kinerjanya tidak mencapai standar dikatakan sebagai orang yang tidak produktif atau berperforma rendah.Kinerja pegawai menurut Sinambela (2011:136) adalah "kemampuan pegawai dalam melakukan sesuatu keahlian tertentu". Kinerja pegawai sangatlah perlu, sebab dengan kinerja ini akan diketahui seberapa jauh kemampuan pegawai dalam melaksanakan tugas yangdibebankan kepadanya. Untuk itu diperlukan penentuan kriteria yang jelas dan terukur secara bersama- 
sama yang dijadikan sebagai acuan. Pendapat lain mengemukakan suatu organisasi dikatakan produktif apabila mencapai tujuannya dan hal itu terjadi dengan mengubah masukan menjadi keluaran dengan biaya rendah. Dengan demikian dapat mendorong motivasi kerja mereka untuk meningkatkan kinerjanya. Berdasarkan dari beberapa definisi diatas, kinerja karyawan dapat disimpulkan sebagai output atau hasil kerja karyawan sesuai dengan tugas dan tanggung jawabnya untuk mencapai tujuan organisasi.

Adapun tujuan Penelitian ini untuk mengetahui apakah :

a. Gaya Kepemimpinan berpengaruh terhadap Motivasi Kerja Karyawan di Kantor BPJS Kesehatan Cabang Langsa?

b. Kepuasan Kerja berpengaruh terhadap Motivasi KerjaKaryawandi Kantor BPJS Kesehatan Cabang Langsa?

c. Gaya Kepemimpinan berpengaruh terhadapKinerja karyawan di Kantor BPJS Kesehatan Cabang Langsa?

d. Kepuasan Kerja berpengaruh terhadap Kinerja karyawan di Kantor BPJS Kesehatan Cabang Langsa?

e. Motivasi kerja berpengaruh terhadap Kinerja Karyawandi Kantor BPJS Kesehatan Cabang Langsa?

\section{METODE PENELITIAN}

\subsection{Lokasi Penelitian}

Lokasi penelitian dilakukan di Provinsi Aceh khususnya Kantor BPJS Keseharan Cabang Langsa yang membawahi beberapa Kantor Kabupaten antara Lain Kabupaten Aceh Timur, Kabupaten Aceh Tamiang, Kabupaten Aceh Tenggara.

\subsection{Populasi}

Populasi didefinisikan sebagai sekelompok orang, kejadian atau segala sesuatu yang mempunyai karakteristik tertentu untuk

\subsection{Defenis Operasional Variabel}

dipelajari dan ditarik kesimpulannya (Sekaran, 2006:59). Populasi dari penelitian ini adalah pegawai/karyawan Kantor BPJS Kesehatan Cabang Langsa. Jumlah populasi pegawai/ karyawan yang aktif bekerja di Kantor BPJS Kesehatan Cabang Langsa adalah 47 orang. Pengambilan sampel penelitian dilakukan terhadap seluruh anggota Populasi yaitu seluruh pegawai BPJS Kesehatan Kantor Cabang Langsa. Sampel dikelompokkan menjadi dua yaitu pegawai pada tingkat lini dan staf. Berdasarkan pengalaman kerja, dikelompokkan menjadi tiga kelompok, yaitu yang bekerja selama 10 Tahun ke bawah, yang bekerja selama 11-20 Tahun dan 20 Tahun ke atas. Dari populasi tersebut, responden mempunyai tingkat pendidikan yang berbeda-beda, dibagi menjadi dua kelompok, yaitu responden yang mempunyai tingkat pendidikan D3, dan responden yang mempunyai tingkat pendidikan S1/S2, Berdasarkan pembagian tersebut pengambilan sampel sudah dianggap mewakili dalam pengumpulan data.

\subsection{Sampel}

MenurutSekaran (2006:123), sampel adalah sebuah proses menyeleksi kumpulan-kumpulan elemen dari sebuah populasi dari penelitian untuk menjadi wakil dari populasitersebut. Pada penelitian ini teknik pengambilan sampel yang digunakan adalah total sampling, dimana seluruh populasi yang ada akan menjadi sampel bagi penelitian.

Hal ini dilakukan dengan pertimbangan bahwa jumlah populasi yang tidak terlalu besar.Dan menurut Roscoe (1975 : 40), ukuran sampel lebih dari 30 dan kurang dari 500 adalah tepat untuk kebanyakan penelitian. Sehingga diputuskan untuk mengambil jumlah sampel sesuai jumlah populasi yang ada, yaitu 47 orang. 
Tabel 1

Operasional Variabel Penelitian

\begin{tabular}{|c|c|c|c|c|}
\hline No. & Variabel & Definisi Operasional & $\begin{array}{l}\text { Indikator } \\
\end{array}$ & Skala \\
\hline \multirow[t]{5}{*}{ A } & \multirow{5}{*}{$\begin{array}{l}\text { Gaya } \\
\text { Kepemimpin } \\
\text { an } \\
(\mathrm{X} 1)\end{array}$} & \multirow[t]{5}{*}{$\begin{array}{l}\text { Armstrong (2003) dalam } \\
\text { (Sudarmanto,2009:133) } \\
\text { menyatakan } \\
\text { kepemimpinanadalah proses } \\
\text { memberi inspirasi kepada semua } \\
\text { karyawan agar bekerjasebaik- } \\
\text { baiknya untuk mencapai hasil } \\
\text { yang diharapkan.Kepemimpinan } \\
\text { adalah cara mengajak karyawan } \\
\text { agar bertindak benar, mencapai } \\
\text { komitmen dan memotivasi } \\
\text { mereka untuk mencapai tujuan } \\
\text { bersama. }\end{array}$} & $\begin{array}{l}\text { a.Mampu memberi arahan dan } \\
\text { petunjuk kepada bawahan dalam } \\
\text { pelaksanaan tugas sehingga } \\
\text { efektif dan efisien } \\
\text { b. Kemampuan seorang pemimpin } \\
\text { dalam memotivasi bawahannya }\end{array}$ & \multirow[t]{5}{*}{ Interval } \\
\hline & & & $\begin{array}{l}\text { a. meminta masukan pada bawahan } \\
\text { agar keputusan yang ditetapkan } \\
\text { berjalan dengan baik } \\
\text { b. menjalankan komunikasi dengan } \\
\text { bawahan sehingga kepemimpinan } \\
\text { menjadi efektif }\end{array}$ & \\
\hline & & & $\begin{array}{l}\text { a. mengaktifkan bawahan baik } \\
\text { dalam pengambilan keputusan } \\
\text { maupun pelaksanaan } \\
\text { b. melakukan pengendalian tugas } \\
\text { tanpa mencampuri tugas pokok } \\
\text { bawahan } \\
\text { c. melaksanakan } \\
\text { pemimpin,bukan tugas pelaksana }\end{array}$ & \\
\hline & & & $\begin{array}{l}\text { a. pendelegasian wewenang kepada } \\
\text { bawahan } \\
\text { b. memberikan kepercayaan kepada } \\
\text { bawahan atas tugas yang } \\
\text { didelegasikan }\end{array}$ & \\
\hline & & & $\begin{array}{l}\text { a. mampu mengatur aktifitas } \\
\text { bawahan agar tugas berjalan } \\
\text { dengan efektif } \\
\text { b. memberikan arahan/briefing } \\
\text { c. melakukan koordinasi dengan } \\
\text { bawahan } \\
\text { d. Melakukan pengawasan }\end{array}$ & \\
\hline \multirow[t]{5}{*}{$\mathrm{B}$} & \multirow[t]{5}{*}{$\begin{array}{l}\text { Kepuasan } \\
\text { Kerja } \\
\text { ( X2 ) }\end{array}$} & \multirow{5}{*}{$\begin{array}{l}\text { kepuasan kerja adalah "sikap } \\
\text { umum terhadap pekerjaan } \\
\text { seseorang yang menunjukkan } \\
\text { perbedaan antara jumlah } \\
\text { penghargaan yag diterima } \\
\text { pekerja dan jumlah yang } \\
\text { mereka yakini seharusnya } \\
\text { mereka terima". Robbins } \\
(2003 ; 78)\end{array}$} & $\begin{array}{ll}\begin{array}{l}\text { a. Kesempatan } \\
\text { pengalaman }\end{array} & \text { memperoleh } \\
\text { b. Kesempatan } & \text { meningkatkan } \\
\text { kemampuan } & \end{array}$ & \multirow[t]{5}{*}{ Interval } \\
\hline & & & $\begin{array}{l}\text { a. Kesempatan memperoleh jenjang } \\
\text { karir yang lebih tinggi } \\
\text { b. Adanya keamanan dan } \\
\text { kenyamanan }\end{array}$ & \\
\hline & & & $\begin{array}{l}\text { a. Gaji } \\
\text { b. Jaminan sosial (kesehatan, hari } \\
\text { tua, kecelakan kerja dan lain-lain }\end{array}$ & \\
\hline & & & $\begin{array}{l}\text { a.Dalam melakukan supervisi, } \\
\text { dapat menjalin hubungan yang } \\
\text { baik dengan bawahan } \\
\text { b.Intensitas komunikasi } \\
\text { melakukan supervisi dengan } \\
\text { bawahan }\end{array}$ & \\
\hline & & & $\begin{array}{l}\text { a. Tempatkerja yang nyaman } \\
\text { (ruangan, tempat parkir dll) } \\
\text { b. Fasilitas karyawan } \\
\text { (perumahan, mess, cuti, } \\
\text { kendaraan, dll ) }\end{array}$ & \\
\hline \multirow[t]{2}{*}{$\mathrm{C}$} & \multirow{2}{*}{$\begin{array}{l}\text { Motivasi } \\
\text { Kerja ( Y1) } \\
\text { / ( X3 ) }\end{array}$} & \multirow[b]{2}{*}{$\begin{array}{l}\text { Motivasi Hasibuan (2012:141) } \\
\text { berasal dari kata } \\
\text { latin'movere”yang artinya } \\
\text { dorongan atau menggerakan. } \\
\text { Motivasi merupakan suatu } \\
\text { uraian yang mencakup berbagai }\end{array}$} & a. Kecukupan penghasilan & \multirow[t]{2}{*}{ Interval } \\
\hline & & & $\begin{array}{l}\text { a. adanva neraturan dukungan } \\
\text { b. Rasa aman dan nyaman dalam } \\
\text { bekeria } \\
\text { c. Adanya jaminan karir } \\
\text { a. Insentif, }\end{array}$ & \\
\hline
\end{tabular}




\begin{tabular}{|c|c|c|c|c|}
\hline No. & Variabel & Definisi Operasional & Indikator & \multirow[t]{11}{*}{ Skala } \\
\hline & & \multirow{10}{*}{$\begin{array}{l}\text { aspek dalam tingkah laku } \\
\text { manusia yang bervariasi } \\
\text { Hasibuan (2012:141) }\end{array}$} & b. Penghargaan pimpinan, & \\
\hline & & & a.Hubungan antar & \\
\hline & & & sesamapegawai.dukungan sesama & \\
\hline & & & b. Hubungan karyawan dengan unit & \\
\hline & & & a. Aktualisasi $\quad$ identitas & \\
\hline & & & pegawai/karvawan & \\
\hline & & & b. Aktualisasi profesionalitas & \\
\hline & & & pegawai/karvawan & \\
\hline & & & c. Aktualisasi akuntabilitas & \\
\hline & & & pegawai/karyawan & \\
\hline \multirow[t]{12}{*}{$\bar{D}$} & \multirow[t]{12}{*}{ Kinerja( Y2 ) } & \multirow{12}{*}{$\begin{array}{l}\text { Menurut Hasibuan(2001:34) } \\
\text { "kinerja (prestasi kerja) adalah } \\
\text { suatu hasil kerja yang dicapai } \\
\text { seseorang dalam melaksanakan } \\
\text { tugas-tugas yang dibebankan } \\
\text { kepadanya yang didasarkan atas } \\
\text { kecakapan, pengalaman dan } \\
\text { kesungguhan serta waktu”. }\end{array}$} & a. Jumlah target yang diselesaikan & \multirow[t]{12}{*}{ Interval } \\
\hline & & & b. Jumlah target yang dihasilkan & \\
\hline & & & & \\
\hline & & & $\begin{array}{ll}\text { a.Kualitas } & \text { pekerjaan }\end{array}$ & \\
\hline & & & $\begin{array}{l}\text { dihasilkan } \\
\text { b Ketramnilan }\end{array}$ & \\
\hline & & & c. Kemampuan & \\
\hline & & & a.Mencapai target tepat waktu & \\
\hline & & & b.Output sesuai target yang ingin & \\
\hline & & & a. Masuk kerja & \\
\hline & & & b. Pulang kerja & \\
\hline & & & a. Mampu bekerja sama & \\
\hline & & & b. Efektif dan efisien & \\
\hline
\end{tabular}

\subsection{Uji Kualitas Data}

Sekaran (2006 : 166) menyebutkan bahwa kesimpulan penelitian yang berupa jawaban atau pemecahan masalah penelitian, dibuat berdasarkan hasil proses pengujian data yang meliputi pemilihan, pengumpulan dan analisis data. Oleh karena itu, kesimpulan tergantung pada kualitas data yang dianalisis dan instrumen yang digunakan untuk mengumpulkan data penelitian. Ada dua konsep untuk mengukur kualitas data, yaitu :

\subsubsection{Uji Validitas}

Uji validitas dilakukan untuk mengetahui apakah alat ukur yang telah disusun dapat digunakan untuk mengukur apa yang hendak diukur secara tepat Uji coba yang dilakukan yang dilakukan sebaiknya dilakukan minimal terhadap 30 orang responden. Sebuah instrumen dikatakan valid apabila dapat mengungkapkan data dari variabel yang diteliti secara tepat dan mempunyai validitas tinggi, tinggi rendahnya validitas instrumen menunjukkan sejauh mana data yang terkumpul tidak menyimpang dari gambaran tentang variabel yang dimaksud (Sekaran,2006:166).Untuk menguji validitas dapat dihitung korelasi antara masing-masing pertanyaan skor total dengan teknik korelasi "product moment" dari Pearson. Perhitungan yang digunakan adalah teknik korelasi produk moment yang dapat diperoleh dengan rumus (Sugiono, $2004:$ 168):

$$
r=\frac{n \sum x y-\left(\sum x\right)\left(\sum y\right.}{\sqrt{\left\{n \sum x^{2}-\left(\sum x\right)^{2}\right\}\left\{n \sum y^{2}-\left(\sum y\right)^{2}\right\}}}
$$

Keterangan :

$\mathrm{r}=$ Koefisien korelasi

$\mathrm{n}=$ Jumlah responden

$\mathrm{y}=$ Variabel endogen

$\mathrm{x}=$ Variabel eksogen

Apabila $\mathrm{r}$ hitung $>\mathrm{r}$ tabel dengan taraf signifikansi $5 \%$ maka dapat disimpulkan ada korelasi yang nyata diantara dimensi-dimensi yang ditetapkan dengan kinerja auditor sehingga dapat dikatakan bahwa kuesioner sebagai alat ukur tersebut adalah valid.

\subsubsection{Uji Reliabilitas}

Uji Reliabilitas yaitu uji yang digunakan untuk mengukur kuesioner yang merupakan indikator dari variabel atau konstruk (Sekaran, 2006: 60). Pengukuran dilakukan hanya sekali dan kemudian hasilnya dibandingkan dengan pertanyaan. Satu kuesioner dikatakan reliabel jika memberikan nilai cronbach alpha> 0,60 (Sekaran, 2006 :60). Teknik cronbach alpha dilakukan dengan menghitung varians tiap butir pertanyaan dan varians total dari pertanyaanpertanyaan. Cronbach alpha dapat diperoleh dengan rumus (Sekaran, 2006:60):

$$
r=\left[\frac{k}{(k-1)}\right]\left[1-\frac{\sum \sigma_{b^{2}}}{\sigma_{i^{2}}}\right]
$$


Keterangan:

$\mathrm{r}=$ Koefisien reliabilitas instrumen

(cronbach alpha)

$\mathrm{k} \quad=$ Banyak butir pertanyaan

$\sum \sigma_{b^{2}}=$ Total varians butir

$\sigma_{i^{2}} \quad=$ Total varians

\subsection{Pengujian Model Analisis Jalur ( Path} Analysis )

David Garson dari North Carolina State University mendefinisikan analisis jalur sebagai "Model perluasan regresi yang digunakan untuk menguji keselarasan matriks korelasi dengan dua atau lebih model hubungan sebab akibat yang dibandingkan oleh peneliti. Modelnya digambarkan dalam bentuk gambar lingkaran dan panah dimana anak panah tunggal menunjukkan sebagai penyebab. Regresi dikenakan pada masing-masing variabel dalam suatu model sebagai variabel tergantung (pemberi respon) sedang yang lain sebagai penyebab. Pembobotan regresi diprediksikan dalam suatu model yang dibandingkan dengan matriks korelasi yang diobservasi untuk semua variabel dan dilakukan juga penghitungan uji keselarasan statistik.

\subsection{Uji asumsi klasik}

\subsubsection{Uji Normalitas}

Menurut Situmorang ( 2008 : 62 ), Uji normalitas bertujuan untuk menguji apakah distribusi sebuah data mengikuti atau mendekati distribusi normal. Ada dua cara untuk mendeteksi apakah residual berdistribusi normal atau tidak, yaitu dengan analisis grafik dan uji statistik. Untuk melihat apakah data berdistribusi normal peneliti menganalisis grafik histogram yang membandingkan antara data observasi dengan distribusi yang mendekati distribusi normal dan juga menganalisis probabilitas plot yang membentuk plot antara nilai-nilai teoritis (sumbu $\mathrm{x}$ ) melawan nilai-nilai yang didapat dari sampel (sumbu y).

a. Pada grafik histogram, dikatakan variabel berdistribusi normal pada grafik histogram yang berbentuk lonceng apabila distribusi data tersebut tidak menceng kekiri atau menceng ke kanan.

b. Apabila plot dari keduanya berbentuk linear (dapat didekati oleh garis lurus), maka hal ini merupakan indikasi bahwa residual menyebar normal. Bila pola-pola titik yang terletak selain di ujung-ujung plot masih berbentuk linear, meskipun ujung-ujung plot agak menyimpang dari garis lurus, dapat dikatakan bahwa sebaran data (dalam hal ini residual) adalah menyebar normal.

\subsubsection{Uji Heteroskledaritas}

Uji hoteroskedatisitas pada prinsipnya ingin menguji apakah sebuah grup mempunyai varians yang sama diantara anggota grup tersebut. Jika varians sama dan ini yang seharusnya terjadi maka dikatakan tidak ada hoteroskedastisitas. Jika varians tidak sama dikatakan terjadi heteroskedastisitas (Situmorang, dkk 2008:63).

\subsubsection{Uji Multikolinearitas}

Uji Multikolinieritas bertujuan untuk menguji apakah dalam model regresi ditemukan adanya korelasi antar variabel bebas. Multikolinieritas ini berarti adanya hubungan yang sempurna atau pasti, diantara beberapa atau semua variabel yang menjelaskan dari model regresi (Situmorang,dkk 2008:63)

\subsection{Uji Hipotesis}

\subsubsection{Uji secara individu (uji $t_{\text {hitung }}$ )}

Hasil uji $t$ dapat dilihat pada tabel coefficients pada kolom sig (significance). Pengambilan keputusan dilakukan berdasarkan perbandingan $t_{\text {hitung }}$ nilai masing-masing koefisien regresi dengan nilai $t_{\text {tabel }}$ (nilai kritis) sesuai dengan tingkat signifikansi yang digunakan yaitu $5 \%$. Jika probabilitas nilai $\mathrm{t}$ atau signifikansi $<0,05$, maka dapat dikatakan bahwa terdapat pengaruh antara variabel bebas terhadap variabel terikat. Atau jika probabilitas nilai $\mathrm{t}$ atau signifikansi $>0,05$, maka dapat dikatakan bahwa tidak terdapat pengaruh yang signifikan masing-masing variabel bebas terhadap variabel terikat..( Situmorang dkk,2008 : 64 ). Untuk menguji hipotesa, dalam penelitian penulis menggunakan uji $\mathrm{t}$ ( $\mathrm{t}$ test) dengan membandingkan antara statistik $t$ hitung dengan statistik $\mathrm{t}$ tabel.maka dapat dijelaskan dengan ketentuan sebagai berikut :

- Jika statistik $\mathrm{t}_{\text {-hitung }}>$ statistik $\mathrm{t}-\mathrm{t}_{\text {abel }}$, maka Ha diterima

- Jika statistik $\mathrm{t}_{\text {-hitung }}<$ statistik $\mathrm{t}-\mathrm{t}_{\text {abel }}$, maka Ha ditolak

Ho1 : Gaya Kepemimpinan tidak berpengaruh terhadap Motivasi Kerja pada karyawan di Kantor BPJS Kesehatan Cabang Langsa.

Ha1: Gaya Kepemimpinan berpengaruh terhadap MotivasiKerja pada karyawan di Kantor BPJS Kesehatan Cabang Langsa. 
Ho2: Kepuasan Kerja tidak berpengaruh terhadap Motivasi Kerja pada karyawan di Kantor BPJS Kesehatan Cabang Langsa.

Ha2: Kepuasan Kerja berpengaruh terhadap Motivasi Kerja pada karyawan di Kantor BPJS Kesehatan Cabang Langsa.

Ho3 : Gaya Kepemimpinan tidak berpengaruh terhadap Kinerjapada karyawan di Kantor BPJS Kesehatan Cabang Langsa.

Ha3 : Gaya Kepemimpinan berpengaruh terhadap Kinerjapada karyawan di Kantor BPJS Kesehatan Cabang Langsa.

Ho4: Kepuasan Kerja tidak berpengaruh terhadap Kinerjapada karyawan di Kantor BPJS Kesehatan Cabang Langsa.

Ha4: Kepuasan Kerja berpengaruh terhadap Kinerjapada karyawan di Kantor BPJS Kesehatan Cabang Langsa.

Ho5: Motivasi kerja tidak berpengaruh terhadap Kinerjapada karyawan di Kantor BPJS Kesehatan Cabang Langsa.

Ha5 : Motivasi kerja berpengaruh terhadap Kinerjapada karyawan di Kantor BPJS Kesehatan Cabang Langsa.

\subsection{Uji Korelasi}

Koefisien korelasi adalah ukuran atau indeks dari hubungan antara dua variabel. Koefisien korelasi besarnya antara -1 sampai +1 . Tanda positif dan negatif menunjukkan arti atau arah dari hubungan koefisien korelasi tersebut. Korelasi positif nilainya berada antara 0 sampai +1 , nilai menjelaskan bahwa apabila suatu variabel naik, maka akan menyebabkan kenaikan pada variabel yang lainnya dan sebaliknya. Korelasi negatif nilainya berada antara -1 sampai dengan 0, nilai tersebut menjelaskan bahwa apabila suatu variabel naik, maka variabel yang lainnya akan turun, dan sebaliknya.( Situmorang dkk,2008 : 64 )

\subsection{Uji Koefisien Determinan ( $\mathbf{R}^{2}$ )}

Pengujian dengan menggunakan uji koefisiensi determinasi $\left(\mathrm{R}^{2}\right)$ digunakan untuk mengukur seberapa besar pengaruh variabel bebas. Uji koefisien determinasi $\left(\mathrm{R}^{2}\right)$ adalah dengan persentasi pengkuadratan nilai koefisien yang ditemukan. Koefisien determinan $\left(\mathrm{R}^{2}\right)$ berkisar antara 0 (nol) sampai dengan 1 (satu), $\left(0 \leq \mathrm{R}^{2} \leq 1\right)$. Hal ini berarti bila $\mathrm{R}^{2}$ semakin besar (mendekati satu), maka dapat dikatakan bahwa pengaruh variabel bebas $\left(\mathrm{X}_{1}, \mathrm{X}_{2}\right.$ dan $\left.\mathrm{X}_{3}\right)$ adalah besar terhadap variabel 'terikat (Y). ( Situmorang dkk 2008: 63 ),

\section{Hasil dan Pembahasan 3.1. Uji Validitas}

Nilai $r$ tabel dengan ketentuan $\mathrm{N}=$ jumlah kasus $=47$ dan tingkat signifikansi sebesar $5 \%$, maka angka yang diperoleh $=0,2816$.

Tabel 1

Validitas Data Variabel X1(Gaya Kepemimpinan)

\begin{tabular}{|c|c|c|c|}
\hline item & $\begin{array}{c}\text { Corrected Item- } \\
\text { Total Correlation }\end{array}$ & r Tabel & Keterangan \\
\hline Pernyataan1 & 0.580 & 0.2816 & Valid \\
Pernyataan2 & 0.692 & 0.2816 & Valid \\
Pernyataan3 & 0.886 & 0.2816 & Valid \\
Pernyataan4 & 0.828 & 0.2816 & Valid \\
Pernyataan5 & 0.886 & 0.2816 & Valid \\
Pernyataan6 & 0.886 & 0.2816 & Valid \\
Pernyataan7 & 0.913 & 0.2816 & Valid \\
Pernyataan8 & 0.971 & 0.2816 & Valid \\
Pernyataan9 & 0.913 & 0.2816 & Valid \\
Pernyataan10 & 0.936 & 0.2816 & Valid \\
Pernyataan11 & 0.913 & 0.2816 & Valid \\
Pernyataan12 & 0.936 & 0.2816 & Valid \\
Pernyataan13 & 0.826 & 0.2816 & Valid \\
\hline
\end{tabular}

Setelah dilakukan pengujian validitas data variabel Gaya Kepemimpinan (X1) yang terlihat pada Tabel 1, seluruh pernyataan adalah valid yaitu nilai corrected item total correlation seluruhnya bernilai lebih besar dari 0,2816. 
Tabel 2

Validitas Data Variabel X2 (Kepuasan Kerja)

\begin{tabular}{|c|c|c|c|}
\hline item & $\begin{array}{c}\text { Corrected Item- } \\
\text { Total Correlation }\end{array}$ & r Tabel & Keterangan \\
\hline Pernyataan1 & 0.614 & 0.2816 & Valid \\
Pernyataan2 & 0.763 & 0.2816 & Valid \\
Pernyataan3 & 0.935 & 0.2816 & Valid \\
Pernyataan4 & 0.818 & 0.2816 & Valid \\
Pernyataan5 & 0.936 & 0.2816 & Valid \\
Pernyataan6 & 0.935 & 0.2816 & Valid \\
Pernyataan7 & 0.813 & 0.2816 & Valid \\
Pernyataan8 & 0.954 & 0.2816 & Valid \\
Pernyataan9 & 0.778 & 0.2816 & Valid \\
Pernyataan10 & 0.829 & 0.2816 & Valid \\
\hline
\end{tabular}

Setelah dilakukan pengujian validitas data yaitu nilai corrected item total correlation variabel Kepuasan Kerja (X2) yang terlihat seluruhnya bernilai lebih besar dari 0,2816. pada Tabel 2 , seluruh pernyataan adalah valid

Tabel 3

Validitas Data Variabel Y1/X3 (Motivasi Kerja)

\begin{tabular}{|c|c|c|c|}
\hline item & $\begin{array}{c}\text { Corrected Item- } \\
\text { Total Correlation }\end{array}$ & r Tabel & Keterangan \\
\hline Pernyataan1 & 0.652 & 0.2816 & Valid \\
Pernyataan2 & 0.751 & 0.2816 & Valid \\
Pernyataan3 & 0.888 & 0.2816 & Valid \\
Pernyataan4 & 0.779 & 0.2816 & Valid \\
Pernyataan5 & 0.948 & 0.2816 & Valid \\
Pernyataan6 & 0.857 & 0.2816 & Valid \\
Pernyataan7 & 0.857 & 0.2816 & Valid \\
Pernyataan8 & 0.948 & 0.2816 & Valid \\
Pernyataan9 & 0.652 & 0.2816 & Valid \\
Pernyataan10 & 0.751 & 0.2816 & Valid \\
Pernyataan11 & 0.888 & 0.2816 & Valid \\
\hline Sumber: Data diolah (2019) & & &
\end{tabular}

Setelah dilakukan pengujian validitas data nilai corrected item total correlation seluruhnya variabel motivasi(Y1/X3) yang terlihat pada bernilai lebih besar dari 0,2816.

Tabel 3, seluruh pernyataan adalah valid yaitu

Tabel 4

Validitas Data Variabel Y2 (Kinerja Karyawan )

\begin{tabular}{|c|c|c|c|}
\hline & $\begin{array}{c}\text { Corrected Item- } \\
\text { Total Correlation }\end{array}$ & r Tabel & Keterangan \\
\hline Pernyataan1 & 0.767 & 0.2816 & Valid \\
Pernyataan2 & 0.754 & 0.2816 & Valid \\
Pernyataan3 & 0.874 & 0.2816 & Valid \\
Pernyataan4 & 0.731 & 0.2816 & Valid \\
Pernyataan5 & 0.895 & 0.2816 & Valid \\
Pernyataan6 & 0.792 & 0.2816 & Valid \\
Pernyataan7 & 0.752 & 0.2816 & Valid \\
Pernyataan8 & 0.893 & 0.2816 & Valid \\
Pernyataan9 & 0.754 & 0.2816 & Valid \\
Pernyataan10 & 0.772 & 0.2816 & Valid \\
Pernyataan11 & 0.872 & 0.2816 & Valid \\
\hline
\end{tabular}


Setelah dilakukan pengujian validitas data variabel Kinerja Karyawan (Y2) yang terlihat pada Tabel 4, seluruh pernyataan adalah valid yaitu nilai corrected item total correlation seluruhnya bernilai lebih besar dari 0,2816.

\subsection{Uji Reliabilitas.}

\section{Tabel 5}

Reliabilitas Data Variabel X1Gaya

Kepemimpinan

\begin{tabular}{|r|r|}
\hline $\begin{array}{c}\text { Cronbach's } \\
\text { Alpha }\end{array}$ & N of Items \\
\hline .971 & 13 \\
\hline
\end{tabular}

Sumber: Data diolah (2019)

Berdasarkan tabel di atasdapat dilihat nilai cronbach's alpha 0,971 lebih besar dari 0,60 berarti data telah reliabel.

Tabel 6

Reliabilitas Data Variabel X2 (Informasi)

\begin{tabular}{|c|c|}
\hline $\begin{array}{c}\text { Cronbach's } \\
\text { Alpha }\end{array}$ & N of Items \\
\hline .966 & 10 \\
\hline
\end{tabular}

Berdasarkan tabel di atasdapat dilihat nilai cronbach's alpha 0,966 lebih besar dari 0,60 berarti data telah reliabel.

Tabel 7

Reliabilitas Data Variabel Y1/X3 (Motivasi)

\begin{tabular}{|c|c|}
\hline $\begin{array}{c}\text { Cronbach's } \\
\text { Alpha }\end{array}$ & $\mathrm{N}$ of Items \\
\hline .958 & 11 \\
\hline
\end{tabular}

Berdasarkan tabel di atasdapat dilihat nilai cronbach's alpha 0,958 lebih besar dari 0,60 berarti data telah reliabel.

Tabel 8

Reliabilitas Data Variabel Y2 (Kinerja

Karyawan )

\begin{tabular}{|r|r|}
\hline $\begin{array}{c}\text { Cronbach's } \\
\text { Alpha }\end{array}$ & N of Items \\
\hline .964 & 11 \\
\hline
\end{tabular}

Berdasarkan tabel di atasdapat dilihat nilai cronbach's alpha 0,964 lebih besar dari 0,60 berarti data telah reliable.

\subsection{Model Analisis Jalur (Path Analysis)}

David Garson dari North Carolina State University mendefinisikan analisis jalur sebagai "Model perluasan regresi yang digunakan untuk menguji keselarasan matriks korelasi dengan dua atau lebih model hubungan sebab akibat yang dibandingkan oleh peneliti. Modelnya digambarkan dalam bentuk gambar lingkaran dan panah dimana anak panah tunggal menunjukkan sebagai penyebab. Regresi dikenakan pada masing-masing variabel dalam suatu model sebagai variabel tergantung (pemberi respon) sedang yang lain sebagai penyebab. Pembobotan regresi diprediksikan dalam suatu model yang dibandingkan dengan matriks korelasi yang diobservasi untuk semua variabel dan dilakukan juga penghitungan uji keselarasan statistik.

Kerangka hubungan kausal empiris antara jalur dapat dibuat melalui persamaan struktur pada Gambar 1 berikut:
Keterangan :

$X_{1}=$ Pendidikan dan latihan

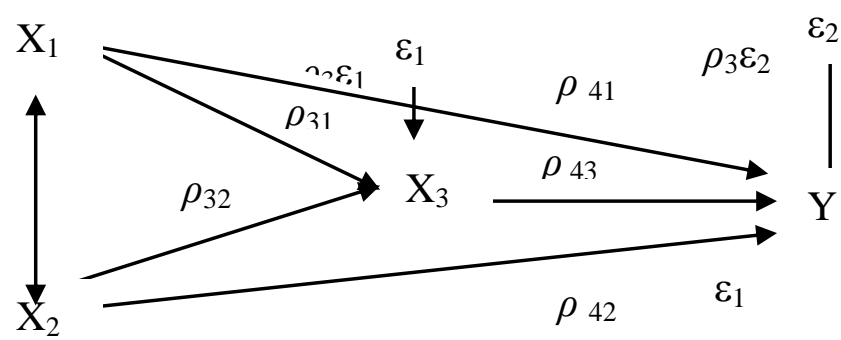

Gambar 1

$$
\begin{aligned}
& \text { Hubungan Struktur } X_{1}, X_{2} \text { dan } X_{3} \text { terhadap } Y \\
& \rho=\text { Koefisien jalur } \\
& \varepsilon=\text { Residu }
\end{aligned}
$$

$X_{2}=$ Pemberian Informasi

$X_{3}=$ Motivasi Kerja

$Y=$ Kinerja Karyawan 
Diagram jalur ini terdiri atas dua substruktur, persamaan strukturalnya dapat dilihat sebagai berikut:
3.3.1. Analisis Jalur Sub-struktur 1

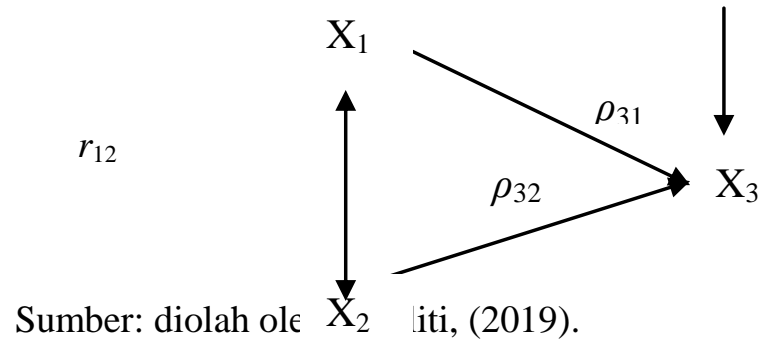

Gambar 2.

Hubungan Sub Struktur 1 variabel $X_{1}$ dan $X_{2}$ terhadap $X_{3}$

\section{b. Sub-struktur 2}

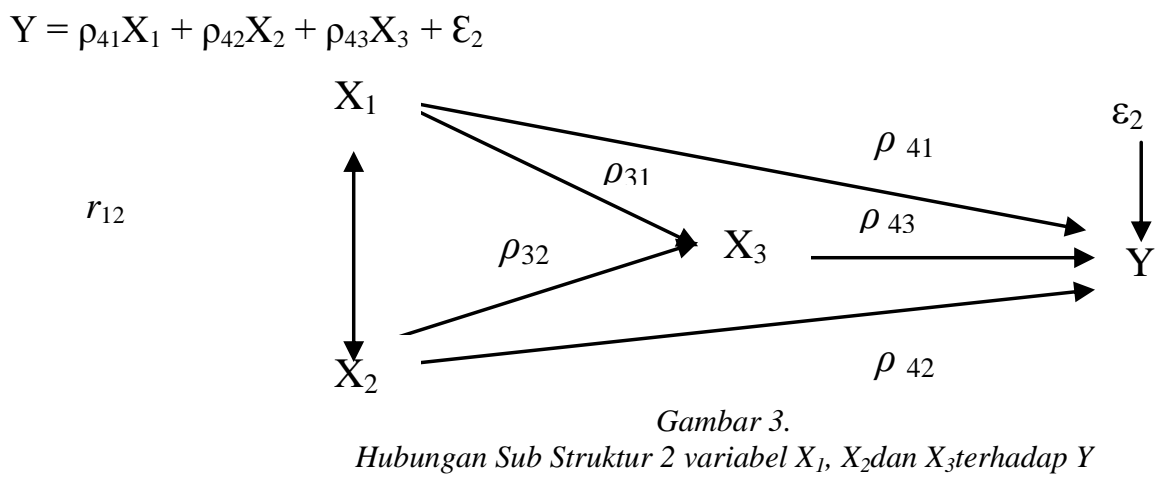

\subsection{Pengujian Sub struktur 1}

\subsubsection{Pengujian Koefisien Determinan $\left(\mathbf{R}^{2}\right)$}

Pengujian dengan menggunakan uji koefisiensi determinasi $\left(\mathrm{R}^{2}\right)$ digunakan untuk mengukur seberapa besar pengaruh variabel bebas. Uji koefisien determinasi $\left(\mathrm{R}^{2}\right)$ adalah dengan persentasi pengkuadratan nilai koefisien yang ditemukan. Koefisien determinan $\left(\mathrm{R}^{2}\right)$ berkisar antara 0 (nol) sampai dengan 1 (satu), $\left(0 \leq R^{2} \leq 1\right)$. Hal ini berarti bila $\mathrm{R}^{2}$ semakin besar (mendekati satu), maka dapat dikatakan bahwa pengaruh variabel bebas $\left(\mathrm{X}_{1}, \mathrm{X}_{2}\right.$ dan $\left.\mathrm{X}_{3}\right)$ adalah besar terhadap variabel terikat $(\mathrm{Y})$.

Hasil koefisien determinan $\left(\mathrm{R}^{2}\right)$ dapat dilihat pada Tabel 9 berikut :

\section{Tabel 9}

Pengujian Koefisien Determinan $\left(\mathrm{R}^{2}\right)$ Sub struktur 1

\begin{tabular}{|l|r|r|r|r|}
\hline Model & $\mathrm{R}$ & $\mathrm{R}$ Square & $\begin{array}{c}\text { Adjusted R } \\
\text { Square }\end{array}$ & $\begin{array}{c}\text { Std. Error of the } \\
\text { Estimate }\end{array}$ \\
\hline 1 & $.793^{\mathrm{a}}$ & .629 & .612 & 3.164 \\
\hline
\end{tabular}

a. Predictors: (Constant), Pemberian Informasi, Pendidikan dan Latihan

b. Dependent Variable: Motivasi Kerja

a. $\mathrm{R}=0,793$ berarti hubungan antara Gaya Kepemimpinan dan Kepuasan Kerja terhadap motivasi kerjadi kantor BPJS Kesehatan Cabang Langsa sebesar $79,3 \%$. Artinya hubungannya cukup erat.

b. Besarnya angka Adjusted square adalah 0,612. Berarti 61,2\% faktor-faktor motivasi kerja di kantor BPJS Kesehatan Cabang Langsa dapat dijelaskan oleh variabel Gaya
Kepemimpinan dan kepuasan kerja. Sedangkan sisanya $38,8 \%$ dipengaruhi oleh faktor-faktor lain.

c. Koefisien residu $\varepsilon_{1}=1-0,612=0,388$.

\subsubsection{Pengujian secara individu (uji $t_{\text {hitung }}$ )}

Uji secara keseluruhan ditunjukkan oleh Tabel 10. 
Tabel 10

Uji $\mathrm{t}_{\text {hitung }}$ Sub struktur 1

Coefficients $^{\mathrm{a}}$

\begin{tabular}{|c|c|c|c|c|c|c|}
\hline & & \multicolumn{2}{|c|}{$\begin{array}{l}\text { Unstandardized } \\
\text { Coefficients }\end{array}$} & $\begin{array}{c}\text { Standardized } \\
\text { Coefficients }\end{array}$ & \multirow[b]{2}{*}{$\mathrm{t}$} & \multirow[b]{2}{*}{ Sig. } \\
\hline \multicolumn{2}{|c|}{ Model } & B & Std. Error & Beta & & \\
\hline 1 & (Constant) & -6.450 & 6.683 & & -965 & .340 \\
\hline & Gaya Kepemimpinan & .462 & .116 & .384 & 3.973 & .000 \\
\hline & Kepuasan Kerja & .627 & .104 & .584 & 6.039 & .000 \\
\hline
\end{tabular}

a. Pengaruh antara Gaya Kepemimpinan dan Motivasi Kerja

Hipotesis penelitian yang akan diuji dirumuskan menjadi hipotesis statistik berikut :

$\mathrm{Ha}=\rho_{31} X_{1}>0 \mathrm{H} 0=\rho_{31} X_{1}=0$

Hipotesis bentuk kalimat :

Ha :Gaya Kepemimpinan berkontribusi secara signifikan terhadap motivasi kerja.

H0: Gaya Kepemimpinan tidakberkontribusi secara signifikan terhadap motivasi kerja.

Selanjutnya, untuk mengetahui signifikansi analisis jalur bandingkan antara nilai probabilitas 0,05 dengan nilai probabilitas sig dengan dasar pengambilan keputusan sebagai berikut :

- Jika nilai probabilitas 0,05 lebih kecil atau sama dengan nilai probabilitas sig atau $(0,05$ $\leq$ sig), maka H0 diterima dan Ha ditolak, artinya tidak signifikan.

- Jika nilai probabilitas 0,05 lebih besar atau sama dengan nilai probabilitas sig atau $(0,05$ $\geq$ sig), maka H0 ditolak dan Ha diterima, artinya signifikan.

Kesimpulan:

Variabel Gaya Kepemimpinan berpengaruh positif dan signifikan terhadap motivasi kerjadi kantor BPJS Kesehatan Cabang Langsa. Hal ini terlihatdari kolom sig (signifikan) pada Tabel 10, Coefficients didapat nilai signifikan 0,000. Kemudian nilai sig 0,000 lebih kecil dari nilai probabilitas 0,05 atau nilai $0,05>0,000$, maka H0 ditolak dan Ha diterima. Artinya, koefisien analisis jalur adalah signifikan, dan nilai $\mathrm{t}_{\text {hitung(3,973) }}>\mathrm{t}_{\text {tabel(2,012) }}$ artinya jika ditingkatkan variabel Gaya Kepemimpinan sebesar satu satuan, maka motivasi kerjaakan meningkat sebesar 0,462 satuan.

\section{b. Pengaruh antara Kepuasan Kerja dan Motivasi Kerja}

Uji secara individual ditunjukkan oleh Tabel 5.19 Coefficients. Hipotesis statistik sebagai berikut :

Ha : $\rho_{32} \mathrm{X}_{2}>0 \mathrm{H}_{0}: \rho_{32} \mathrm{X}_{2}=0$

Hipotesis dalam bentuk kalimat :

$\mathrm{Ha}$ :Kepuasan Kerja berkontribusi secara signifikan terhadap motivasi kerja.

H0 :Kepuasan Kerja tidakberkontribusi secara signifikan terhadap motivasi kerja.

Kesimpulan :

Variabel Kepuasan Kerja berpengaruh positif dan signifikan terhadap motivasi kerjadi kantor BPJS Kesehatan Cabang Langsa. Hal ini terlihat dari kolom sig (signifikan) pada Tabel 10 , Coefficients didapat nilai sig 0,000 . Nilai sig 0,000 lebih kecil dari nilai probabilitas 0,05 atau nilai $0,05>0,000$, maka Ha diterima dan H0ditolak. Artinya, koefisien analisis jalur adalah signifikan, dan nilai $\mathrm{t}_{\text {hitung(6,039) }}>\mathrm{t}_{\text {tabel(2,012) }}$ artinya jika ditingkatkan variabel Kepuasan Kerja sebesar satu satuan, maka motivasi kerjaakan meningkat sebesar 0,627 satuan.

Hasil analisis membuktikan bahwa nilai koefisien jalur pada sub-struktur 1 adalah signifikan.

\subsection{Uji Korelasi}

Koefisien korelasi adalah ukuran atau indeks dari hubungan antara dua variabel. Koefisien korelasi besarnya antara -1 sampai +1 . Tanda positif dan negatif menunjukkan arti atau arah dari hubungan koefisien korelasi tersebut. Korelasi positif nilainya berada antara 0 sampai +1 , nilai menjelaskan bahwa apabila suatu variabel naik, maka akan menyebabkan kenaikan pada variabel yang lainnya dan sebaliknya. Korelasi negatif nilainya berada antara -1 sampai dengan 0 , nilai tersebut 
menjelaskan bahwa apabila suatu variabel naik, maka variabel yang lainnya akan turun, dan

sebaliknya. Korelasi antar variabel dapat dilihat Tabel 11

Uji Korelasi Sub struktur 1

Correlations

\begin{tabular}{|ll|r|r|r|}
\hline & & $\begin{array}{c}\text { Gaya } \\
\text { Kepemimpina } \\
\mathrm{n}(\mathrm{X} 1)\end{array}$ & $\begin{array}{c}\text { Kepuasan } \\
\text { Kerja (X2) }\end{array}$ & $\begin{array}{c}\text { Motifasi Kerja } \\
\text { (Y1/X3) }\end{array}$ \\
\hline Gaya Kepemimpinan & Pearson Correlation & 1 & $.314^{*}$ & $.567^{* *}$ \\
(X1) & Sig. (2-tailed) & .032 & .000 \\
& $\mathrm{~N}$ & 47 & 47 & 47 \\
\hline Kepuasan Kerja (X2) & Pearson Correlation & $.314^{*}$ & 1 & $.704^{* *}$ \\
& Sig. (2-tailed) & .032 & 47 & .000 \\
& $\mathrm{~N}$ & 47 & $.704^{* *}$ & 4 \\
\hline Motifasi Kerja (Y1/X3) & Pearson Correlation & .000 & .000 & 47 \\
& Sig. (2-tailed) & $\mathrm{N}$ & 47 & 47 \\
& $\mathrm{~N}$ & & &
\end{tabular}

*. Correlation is significant at the 0.05 level (2-tailed).

**. Correlation is significant at the 0.01 level (2-tailed).

Dari hasil pengolahan data tersebut, dapat disimpulkan bahwa korelasi antar variabel adalah positif karena berada diantara 0 sampai +1 . Nilai korelasi menjelaskan bahwa apabila variabel Gaya Kepemimpinan naik, maka akan menyebabkan kenaikan pada variabel Kepuasan Kerja dan sebaliknya. Korelasi antara Gaya

Kepemimpinan dan Kepuasan Kerja sebesar 0,314 .

\subsubsection{Model Koefisien Sub-Struktur 1}

Model koefisien sub-struktur 1 dapat digambarkan seperti Gambar 4 berikut :

$\varepsilon_{1}=0,388$

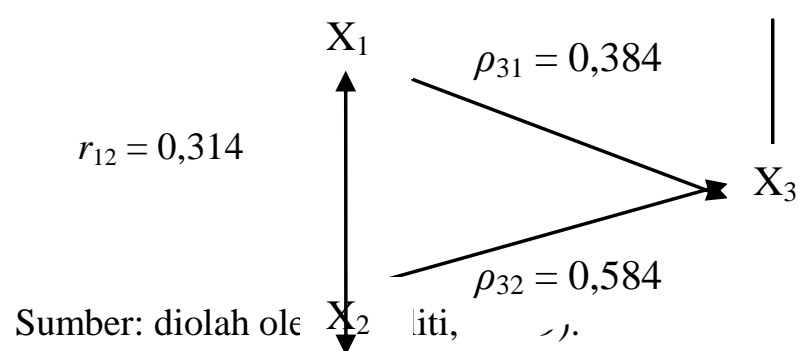

Gambar 4

Hubungan Kausal Empiris Sub Struktur 1 variabel $X_{1}$ dan $X_{2}$ terhadap $X_{3}$

Dari model koefisien regresi sub-struktur 1 diatas dapat dirumuskan persamaan struktural sebagai berikut :

$X_{3}=\rho_{31} X_{1}+\rho_{32} X_{2}+\varepsilon_{1}$ $X_{3}=0,384 X_{1}+0,584 X_{2}+0,388 X_{3}$

Dari hasil analisis diatas, maka dapat disimpulkan :

a. Pengaruh variabel Gaya Kepemimpinan terhadap motivasi kerjasebesar 0,384 atau $38,4 \%$

b. Pengaruh variabel Kepuasan Kerja terhadap motivasi kerjasebesar 0,584 atau 58,4\% c. Pengaruh variabel Gaya Kepemimpinan dan Kepuasan Kerja secara gabungan terhadap motivasi kerjasebesar 0,612 atau 61,2\%

d. Pengaruh variabel-variabel lain diluar model analisis jalur ini sebesar 0,388 atau 38,8\%

e. Korelasi antara variabel Gaya Kepemimpinan dan Kepuasan Kerja sebesar 0,314 .

3.5.2. Pengujian Sub struktur 2

3.5.2.1. Pengujian Koefisien Determinan $\left(\mathbf{R}^{2}\right)$ 
Pengujian dengan menggunakan uji koefisiensi determinasi $\left(\mathrm{R}^{2}\right)$ digunakan untuk mengukur seberapa besar pengaruh variabel bebas. Uji koefisien determinasi $\left(\mathrm{R}^{2}\right)$ adalah dengan persentasi pengkuadratan nilai koefisien yang ditemukan. Koefisien determinan $\left(\mathrm{R}^{2}\right)$ berkisar antara 0 (nol) sampai dengan 1 (satu),

Tabel 12

Pengujian Koefisien Determinan $\left(\mathrm{R}^{2}\right)$ Sub struktur 2 Model Summary ${ }^{\mathrm{b}}$

\begin{tabular}{|l|r|r|r|r|}
\hline Model & \multicolumn{1}{|c|}{$\mathrm{R}$} & R Square & $\begin{array}{c}\text { Adjusted R } \\
\text { Square }\end{array}$ & $\begin{array}{c}\text { Std. Error of } \\
\text { the Estimate }\end{array}$ \\
\hline 1 & $.835^{\mathrm{a}}$ & .697 & .676 & 2.947 \\
\hline
\end{tabular}

a. Predictors: (Constant), Motivasi Kerja, Kepuasan Kerja, Gaya Kepemimpinan

b. Dependent Variable: Kinerja Karyawan a) $\mathrm{R}=0,835$ berarti hubungan antara Gaya Kepemimpinan,Kepuasan Kerja dan motivasi kerjaterhadap Kinerjadi kantor BPJS Kesehatan Cabang Langsa sebesar $83,5 \%$. Artinya hubungannya sangat erat.

b) Besarnya angka Adjusted square adalah 0,676. Berarti 67,6\% faktor-faktor Kinerja Karyawandi kantor BPJS Kesehatan Cabang Langsadapat dijelaskan oleh pendidikan dan

latihan,Kepuasan Kerja dan motivasi kerja. Sedangkan sisanya 32,4\% dipengaruhi oleh faktor-faktor lain.

c) Koefisien residu $\varepsilon_{2}=1-0,676=0,324$.

\subsubsection{Pengujian secara individu (uji $t_{\text {hitung }}$ )}

Uji secara individual ditunjukkan oleh Tabel 13

Tabel 13

Uji $t_{\text {hitung }}$ Sub struktur 2

Coefficients $^{\mathrm{a}}$

\begin{tabular}{|c|c|c|c|c|c|}
\hline \multirow[b]{2}{*}{ Model } & \multicolumn{2}{|c|}{$\begin{array}{l}\text { Unstandardized } \\
\text { Coefficients }\end{array}$} & \multirow{2}{*}{$\begin{array}{c}\begin{array}{c}\text { Standardized } \\
\text { Coefficients }\end{array} \\
\text { Beta }\end{array}$} & \multirow[b]{2}{*}{$\mathrm{t}$} & \multirow[b]{2}{*}{ Sig. } \\
\hline & $\mathrm{B}$ & Std. Error & & & \\
\hline $1 \quad$ (Constant) & 3.017 & 6.291 & & .480 & .634 \\
\hline Gaya Kepemimpinan (X1) & .288 & .126 & .235 & 2.277 & .028 \\
\hline Kepuasan Kerja (X2) & .165 & .131 & .151 & 2.265 & .023 \\
\hline Motifasi Kerja (Y1/X3) & .580 & .140 & .569 & 4.129 & .000 \\
\hline
\end{tabular}

a. Dependent Variable: Kinerja (Y2)

1. Pengaruh antara Gaya Kepemimpinan dan Kinerja Karyawan

Hipotesis penelitian yang akan diuji dirumuskan menjadi hipotesis statistik berikut :

$$
\mathrm{Ha}=\rho_{41} \mathrm{X}_{1}>0 \mathrm{H}_{0}=\rho_{41} \mathrm{X}_{1}=0
$$

Hipotesis bentuk kalimat :

Ha : Gaya Kepemimpinan berkontribusi secara signifikan terhadap Kinerja Karyawan .

H0: Gaya Kepemimpinan tidakberkontribusi secara signifikan terhadap Kinerja Karyawan .

Selanjutnya, untuk mengetahui signifikansi analisis jalur bandingkan antara nilai probabilitas 0,05 dengan nilai probabilitas sig dengan dasar pengambilan keputusan sebagai berikut :

a. Jika nilai probabilitas 0,05 lebih kecil atau sama dengan nilai probabilitas sig atau $(0,05$ $\leq$ sig), maka H0 diterima dan Ha ditolak, artinya tidak signifikan.

b. Jika nilai probabilitas 0,05 lebih besar atau sama dengan nilai probabilitas sig atau $(0,05$ $\geq$ sig), maka HOditolak dan Ha diterima, artinya signifikan.

Keputusan :

Variabel Gaya Kepemimpinan berpengaruh positif dan signifikan terhadap Kinerja Karyawan di kantor BPJS Kesehatan Cabang 
Langsa Medan. Hal ini terlihat dari kolom sig (signifikan) pada Tabel 5.24Coefficients didapat nilai signifikan 0,028. Kemudian nilai sig 0,028 lebih kecil dari nilai probabilitas 0,05 atau nilai $0,05>0,028$, maka H0 ditolak dan Ha diterima. Artinya, koefisien analisis jalur adalah signifikan, dan nilai $\mathrm{t}_{\text {hitung(2,277) }}>\mathrm{t}_{\text {tabel(2,012) }}$ artinya jika ditingkatkan variabel Gaya Kepemimpinan sebesar satu satuan, maka Kinerja Karyawan akan meningkat sebesar 0,288 satuan.

\section{Pengaruh antara Kepuasan Kerja dan Kinerja Karyawan}

Uji secara individual ditunjukkan oleh Tabel 5.24Coefficients. Hipotesis statistik berikut :

$$
\mathrm{Ha}: \rho_{42} \mathrm{X}_{2}>0 \mathrm{H}_{0}: \rho_{42} \mathrm{X}_{2}=0
$$

Hipotesis bentuk kalimat :

Ha: Kepuasan Kerja berkontribusi secara signifikan terhadap Kinerja Karyawan.

H0: Kepuasan Kerja tidakberkontribusi secara signifikan terhadap Kinerja Karyawan

Dengan demikian :

Variabel Kepuasan Kerja berpengaruh positif dan signifikan terhadap Kinerja Karyawan di kantor BPJS Kesehatan Cabang Langsa. Hal ini terlihat dari kolom sig (signifikan) pada Tabel 5.24Coefficients didapat nilai signifikan 0,023. Kemudian nilai sig 0,023 lebih kecil dari nilai probabilitas 0,05 atau nilai $0,05>0,023$, maka H0ditolak dan Ha diterima. Artinya, koefisien analisis jalur adalah signifikan, dan nilai $\mathrm{t}_{\text {hitung(2,265) }}>\mathrm{t}_{\text {tabel(2,012) }}$ artinya jika ditingkatkan variabel Kepuasan Kerja sebesar satu satuan, maka Kinerja Karyawan akan meningkat sebesar 0,165 satuan.

\section{Pengaruh antara Motivasi Kerja dan Kinerja Karyawan}

Uji secara individual ditunjukkan oleh Tabel 5.24Coefficients. Hipotesis statistik berikut :

$$
\mathrm{Ha}: \rho_{43} \mathrm{X}_{3}>0 \mathrm{H}_{0}: \rho_{43} \mathrm{X}_{3}=0
$$

Ha : motivasi kerjaberkontribusi secara signifikan terhadap Kinerja Karyawan .

H0: motivasi kerjatidakberkontribusi secara signifikan terhadap Kinerja Karyawan

Dengan demikian Kesimpulannya adalah :

Variabel motivasi kerjaberpengaruh positif dan signifikan terhadap Kinerja Karyawan di kantor BPJS Kesehatan Cabang Langsa Medan. Hal ini terlihat dari kolom sig (signifikan) pada Tabel 5.24Coefficients didapat nilai signifikan 0,000 . Kemudian nilai sig 0,000 lebih kecil dari nilai probabilitas 0,05 atau nilai $0,05>0,000$, maka $\mathrm{H}_{0}$ ditolak dan $\mathrm{Ha}$ diterima. Artinya, koefisien analisis jalur adalah signifikan, dan nilai $\mathrm{t}_{\text {hitung(4,129) }}>\mathrm{t}_{\text {tabel(2,012) }}$ artinya jika ditingkatkan variabel motivasi kerjasebesar satu satuan, maka Kinerja Karyawan akan meningkat sebesar 0,800 satuan.

\subsubsection{Uji Korelasi}

Koefisien korelasi adalah ukuran atau indeks dari hubungan antara dua variabel. Koefisien korelasi besarnya antara -1 sampai +1 . Tanda positif dan negatif menunjukkan arti atau arah dari hubungan koefisien korelasi tersebut. Korelasi positif nilainya berada antara 0 sampai +1 , nilai menjelaskan bahwa apabila suatu variabel naik, maka akan menyebabkan kenaikan pada variabel yang lainnya dan sebaliknya. Korelasi negatif nilainya berada antara -1 sampai dengan 0 , nilai tersebut menjelaskan bahwa apabila suatu variabel naik, maka variabel yang lainnya akan turun, dan sebaliknya.

Korelasi antar variabel dapat dilihat pada Tabel 14 berikut :

\section{Tabel 14}

Uji Korelasi Sub struktur 2 Correlations

\begin{tabular}{|ll|r|r|r|r|}
\hline & \multicolumn{1}{|c|}{$\begin{array}{c}\text { Gaya } \\
\text { Kepemimpinan } \\
(\mathrm{X} 1)\end{array}$} & $\begin{array}{c}\text { Kepuasan } \\
\text { Kerja (X2) }\end{array}$ & $\begin{array}{c}\text { Motifasi } \\
\text { Kerja } \\
(\mathrm{Y} 1 / \mathrm{X} 3)\end{array}$ & $\begin{array}{c}\text { Kinerja } \\
(\mathrm{Y} 2)\end{array}$ \\
\hline Gaya & Pearson Correlation & 1 & $.314^{*}$ & $.567^{* * *}$ & $.605^{* * *}$ \\
Kepemimpinan & Sig. (2-tailed) & & .032 & .000 & .000 \\
(X1) & $\mathrm{N}$ & 47 & 47 & 47 & 47 \\
\hline Kepuasan & Pearson Correlation & $.314^{*}$ & 1 & $.704^{* * *}$ & $.626^{*}$ \\
Kerja (X2) & Sig. (2-tailed) & .032 & & .000 & .000 \\
& N & 47 & 47 & 47 & 47 \\
\hline Motifasi Kerja & Pearson Correlation & $.567^{* * *}$ & $.704^{* *}$ & 1 & $.809^{* *}$ \\
(Y1/X3) & Sig. (2-tailed) & .000 & .000 & & .000 \\
& N & 47 & 47 & 47 & 47 \\
\hline
\end{tabular}




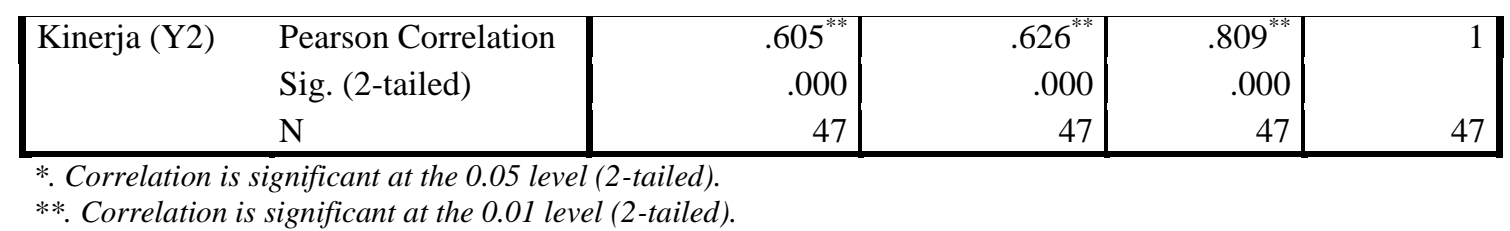

Dari hasil pengolahan data diatas, dapat disimpulkan bahwa korelasi antar variabel adalah positif karena berada diantara 0 sampai +1. Nilai korelasi menjelaskan bahwa apabila suatu variabel naik, maka akan menyebabkan kenaikan pada variabel lainnya dan sebaliknya.

Keterangan :

a. Korelasi antara Gaya Kepemimpinan dan Kinerja Karyawandan sebaliknya sebesar 0,605 . b. Korelasi antara Gaya Kepemimpinan dan motivasi kerjadan sebaliknya sebesar 0,567.

c. Korelasi antara Kepuasan Kerja dan motivasi kerjasebesar 0,704.

d.Korelasi antara Kepuasan Kerja dan motivasi kerjasebesar 0,626.

e. Korelasi antara motifasi kerja dan Kinerja Karyawan sebesar 0,809

\subsubsection{Model Koefisien Sub-Struktur 2}

Model koefisien sub-struktur 2 dapat digambarkan seperti Gambar 5 berikut :

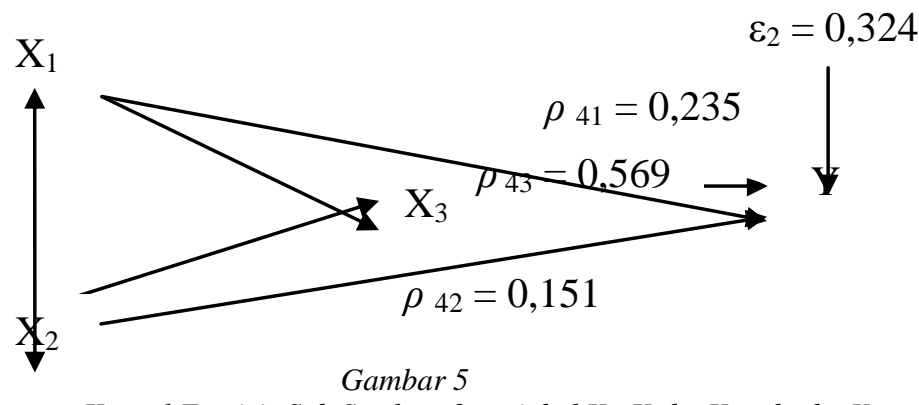

Hubungan Kausal Empiris Sub Struktur 2 variabel $X_{1}, X_{2}$ dan $X_{3}$ terhadapY

Dari model koefisien regresi sub-struktur 2 diatas dapat dirumuskan persamaan struktural sebagai berikut :

$$
\begin{aligned}
& Y=\rho_{41} X_{1}+\rho_{42} X_{2}+\rho_{43} X_{3}+\varepsilon_{2} \\
& Y=0,235 X_{1}+0,151 X_{2}+0,569 X_{3}+0,324 Y
\end{aligned}
$$

Dari hasil analisis diatas, maka dapat disimpulkan :

a. Pengaruh variabel Gaya Kepemimpinan terhadap Kinerja Karyawan sebesar 0,235 atau $23,5 \%$.

b. Pengaruh variabel Kepuasan Kerja terhadap Kinerja Karyawan sebesar 0,151 atau $15,1 \%$.

c. Pengaruh variabel motivasi kerjaterhadap Kinerja Karyawan sebesar 0,569 atau $56,9 \%$.

d. Pengaruh variabel pendidikan dan latihan,

Kepuasan Kerja dan motivasi kerjasecara gabungan terhadap Kinerja Karyawan sebesar 0,676 atau $67,6 \%$

e. Pengaruh variabel-variabel lain diluar model analisis jalur ini sebesar 0,324 atau 32,4\%

\subsection{Penjelasan Hasil Analisis Jalur}

Berdasarkan hasil perhitungan secara keseluruhan, maka dapat dijelaskan dan dibahas sehingga memberikan informasi secara objektif sebagai berikut :

1. Hipotesis pertama yang berbunyi "Gaya Kepemimpinan berpengaruh positif dan signifikan terhadap motivasi kerja di Kantor BPJS Kesehatan Cabang Langsa.”. Dari hasil pengujian sub struktur 1 dapat dilihat bahwa semua variabel dapat diterima. Dengan demikian hasil temuan analisis pada sub struktur 1 ini memberikan informasi bahwa Gaya Kepemimpinan berpengaruh positif dan signifikan terhadap motivasi kerja di Kantor BPJS Kesehatan Cabang Langsa.

2. Hipotesis kedua yang berbunyi "Kepuasan Kerja berpengaruh positif dan signifikan terhadap motivasi kerja di Kantor BPJS Kesehatan Cabang Langsa.'Dari hasil pengujian sub struktur 1 dapat dilihat bahwa semua variabel dapat diterima. Dengan demikian hasil temuan analisis pada sub struktur 1 ini memberikan informasi bahwa 
Kepuasan Kerja berpengaruh positif dan signifikan terhadap motivasi kerja di Kantor BPJS Kesehatan Cabang Langsa.

3. Hipotesis ketiga yang berbunyi "Gaya Kepemimpinan berpengaruh positif dan signifikan terhadap Kinerja Karyawan di Kantor BPJS Kesehatan Cabang Langsa."Dari hasil pengujian sub struktur 2 dapat dilihat bahwa semua variabel dapat diterima. Dengan demikian hasil temuan analisis pada sub struktur 2 ini memberikan informasi bahwa Gaya Kepemimpinan berpengaruh positif dan signifikan terhadap Kinerja Karyawan di Kantor BPJS Kesehatan Cabang Langsa.

4. Hipotesis keempat yang berbunyi "Kepuasan Kerja berpengaruh positif dan signifikan terhadap Kinerja Karyawan di Kantor BPJS Kesehatan Cabang Langsa."Dari hasil pengujian sub struktur 2 dapat dilihat bahwa semua variabel dapat diterima. Dengan demikian hasil temuan analisis pada sub struktur 2 ini memberikan informasi bahwa Kepuasan Kerja berpengaruh positif dan signifikan terhadap Kinerja Karyawan di Kantor BPJS Kesehatan Cabang Langsa.

5. Hipotesis kelima yang berbunyi "Motivasi kerja berpengaruh positif dan signifikan terhadap Kinerja Karyawan di Kantor BPJS Kesehatan Cabang Langsa.”Dari hasil pengujian sub struktur 2 dapat dilihat bahwa semua variabel dapat diterima. Dengan demikian hasil temuan analisis pada sub struktur 2 ini memberikan informasi bahwa Motivasi kerja berpengaruh positif dan signifikan terhadap Kinerja Karyawan di Kantor BPJS Kesehatan Cabang Langsa.

Jawaban terhadap masalah penelitian tersebut dapat diringkas melalui Tabel 5.26 yang memaparkan besarnya pengaruh secara proporsional antar variabel.

Tabel 15

Pengaruh Secara Proporsional Antar Variabel

\begin{tabular}{|c|c|c|c|c|c|}
\hline \multirow{2}{*}{ Variabel } & \multirow{2}{*}{$\begin{array}{c}\text { Koefisien } \\
\text { Jalur }\end{array}$} & Langsung & $\begin{array}{c}\text { Tidak langsung } \\
\text { melalui } \mathrm{X}_{3}\end{array}$ & Total & \multirow{2}{*}{$\begin{array}{c}\text { Pengaruh bersama } \\
\left(\mathrm{R}^{2} \mathrm{YX}_{\mathrm{k}}\right)\end{array}$} \\
\cline { 3 - 5 } & 0,235 & 0,235 & 0,218 & 0,453 & - \\
\hline $\mathrm{X}_{1}$ & 0,151 & 0,151 & 0,332 & 0,483 & - \\
\hline $\mathrm{X}_{2}$ & 0,569 & 0,569 & - & 0,569 & - \\
\hline $\mathrm{X}_{3}$ & 0,388 & 0,151 & - & - & - \\
\hline$\varepsilon_{1}$ & 0,324 & 0.105 & - & - & - \\
\hline$\varepsilon_{2}$ & - & & - & - & 0,629 \\
\hline $\mathrm{X}_{1}$ dan $\mathrm{X}_{2}$ & - & - & - & - & 0,697 \\
\hline $\begin{array}{l}\mathrm{X}_{1}, \mathrm{X}_{2} \text { dan } \\
\mathrm{X}_{3}\end{array}$ \\
Sumber: diolah oleh peneliti, (2016).
\end{tabular}

Keterangan :

a. Pada variabel $X_{1}$ Gaya Kepemimpinan koefisien jalur dan pengaruh langsung nilainya sebesar 0,235. Ini diperoleh dari nilai beta pada standardized coefficients uji sub-struktur 2 dan pengaruh tidak langsungnya diperoleh dari hasil perkalian antara $\rho_{31} \times \rho_{43}=0,384 \times 0,569=0,218$. Dan pengaruh total diperoleh dari hasil penjumlahan antara pengaruh langsung dan pengaruh tidak langsung $=0,235+0,218=$ 0,453

b. Pada variabel $\mathrm{X}_{2}$ Kepuasan Kerjakoefisien jalur nilainya dan pengaruh langsung nilainya sebesar 0,151 . Ini diperoleh dari nilai beta pada standardized coefficients uji sub-struktur 2 dan pengaruh tidak langsungnya diperoleh dari hasil perkalian antara $\rho_{32} \times \rho_{43}=0,584 \times 0,569=0,332$.
Dan pengaruh total diperoleh dari hasil penjumlahan antara pengaruh langsung dan pengaruh tidak langsung $=0,151+0,332=$ 0,483 .

c. Pada variabel $\mathrm{X}_{3}$ (Motivasi), koefisien jalur nilainya dan pengaruh langsung nilainya sebesar 0,596. Ini diperoleh dari nilai beta pada standardized coefficients uji substruktur 2.

d. Nilai $\varepsilon_{1}$ pada koefisien jalur sebesar 0,649 diperoleh dari $=(1-$ nilai adjusted $R$ square sub-struktur 1$)=(1-0,612)=0,388$ dan pengaruh langsungnya diperoleh dari hasil pengkuadratan dari nilai koefisien jalur $=$ $(0,388)^{2}=0,151$.

e. Nilai $\varepsilon_{2}$ pada koefisien jalur sebesar 0,310 diperoleh dari dari $=(1-$ nilai adjusted $R$ square sub-struktur 2$)=(1-0,676)=0,324$ dan pengaruh langsungnya diperoleh dari 
hasil pengkuadratan dari nilai koefisien jalur $=(0,324)^{2}=0,105$.

f. Besarnya pengaruh bersama antara $X_{1}$ dan $\mathrm{X}_{2}$ yaitu diperoleh dari besarnya nilai $R$ Square dari pengujian sub-struktur 1 yaitu sebesar 0,629.

g. Besarnya pengaruh bersama antara $X_{1}$, $\mathrm{X}_{2}$ dan $\mathrm{X}_{3}$ yaitu diperoleh dari besarnya nilai
$R$ Square dari pengujian sub-struktur 2 yaitu sebesar 0,697.

Berdasarkan hasil dari koefisien jalur pada sub-struktur 1 dan sub-struktur 2, maka dapat digambarkan secara keseluruhan yang menggambarkan hubungan kausal empiris antar variabel $X_{1}, X_{2}$ dan $X_{3}$ terhadap $Y$ sebagai berikut :

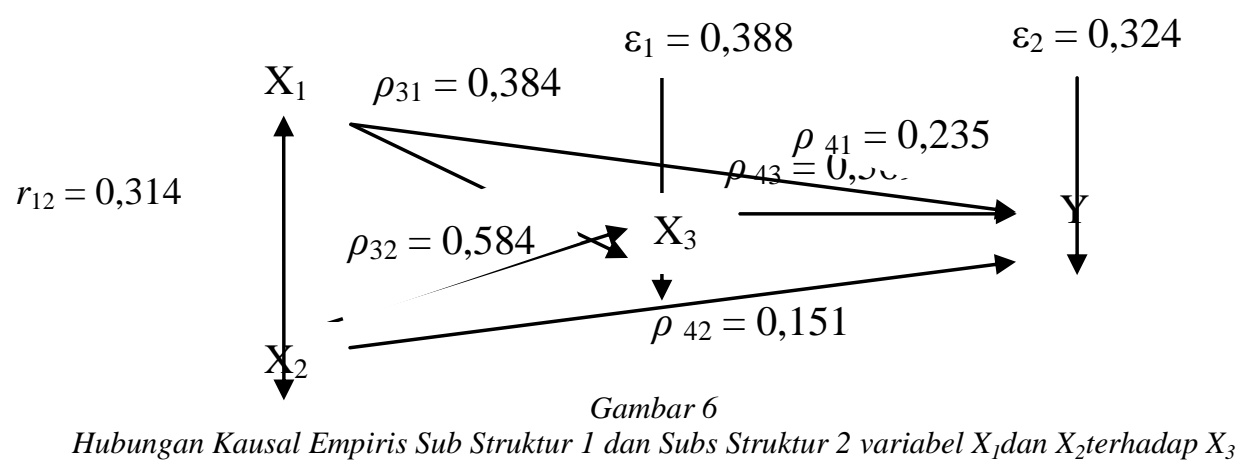

\section{Kesimpulan}

Berdasarkan hasil analisis yang telah dibahas pada bab terdahulu, maka dapat ditarik kesimpulan sebagai berikut:

1. Hasil temuan analisis memberikan informasi bahwa Gaya Kepemimpinanberpengaruh positif dan signifikan terhadap Motivasi Kerja di Kantor BPJS Kesehatan Cabang Langsa sebesar 0,384 atau 38,4\%.

2. Hasil temuan analisis memberikan informasi bahwa Kepuasan Kerja berpengaruh positif dan signifikan terhadap Motivasi Kerja di Kantor BPJS Kesehatan Cabang Langsa sebesar 0,584 atau $58,4 \%$.

3. Hasil temuan analisis memberikan informasi bahwa Gaya Kepemimpinan (diklat)berpengaruh positif dan signifikan terhadap Kinerja Organisasi di Kantor BPJS Kesehatan Cabang Langsa sebesar 0,235 atau $23,5 \%$.

4. Hasil temuan analisis memberikan informasi bahwa Kepuasan Kerja berpengaruh positif dan signifikan terhadap Kinerja Karyawan di Kantor BPJS Kesehatan Cabang Langsa sebesar 0,151 atau $15,1 \%$.

5. Hasil temuan analisis memberikan informasi bahwa Motivasi kerja berpengaruh positif dan signifikan terhadap Kinerja Karyawan di Kantor BPJS Kesehatan Cabang Langsa sebesar 0,569 atau $56,9 \%$.

\section{DAFTAR PUSTAKA}

As'ad, 2001, Seri Ilmu Sumber Daya Manusia Psikologi Industri, Yogyakarta :Liberty.
Afandi,Budi, 2016, Concept \&Indikator\& Human Resource Management for Management Research, edisi 1 cetakan 1, Jakarta Deepublish

Anogara, Pandji,2009, Manajemen Bisnis,Jakarta : PT.Rineka Cipta

Arep, IshakdanTanjung, Herry, 2003, ManajemenMotivasi, Jakarta, PT. Grafindo

Armstrong. Michael, 2009, Armstrong's Handbook of Human Resource Management Practice 11 th Edition. United Kingdom Kogan Page

Bangun, Wilson 2012, Manajemen Sumber Daya Manusia, Jakarta: Erlangga

Brahmasari,Ida Ayu dan Agus Suprayetno,2008. Pengaruh Motivasi Kerja, Kepemimpinan dan Budaya Organisasi Terhadap Kepuasan Kinerja Karyawan serta Dampaknya pada Kinerja Perusahaan ( ( Studi kasus PT. Pei Hai International Wiratama Indonesia). Journal Manajemen dan Kewirausahaan Vol.10 No 2 September 2008

Dharma, Surya,(2009), Manajemen kinerja, Filsafat, teori dan Penerapannya, Yogyakarta, Pustaka Pelajar

David Garson,(2003) Path Analysis , North Carolina State University, (http// www.mitrariset.com/2009/04/analisisjalur-path-analysis.html ( Mei 2010 )

Dubrin,Andrew J, The Complete Ideal's Guide: Leadership,Edisi kedua.Jakarta Prenada, 
Hasibuan, MalayuSP,2001 ,Manajemen : Dasar, PengertiandanMasalah, EdisirevisiJakarta, PT. BumiAksara -2004, Manajemen : Dasar, Pengertian dan Masalah, Jakarta, PT. Bumi Aksara -,2008, Manajemen Dasar, Pengertian, Dan Masalah. Jakarta, PT Bumi Aksara.

--- Manajemen
Sumber Daya Manusia, Jakarta, PT. BumiAksara - 2014.Manajemen Sumber Daya Manusia (Edisi Revisi). Jakarta : BumiAksara.

Kreitner R, \& Kinicki, A. 2001. Organizational Behavior, Fith Edition,

International Edition, Mc Graw-Hill companies. Inc

Kuncoro, Mudrajad,(2003 ), Metode Riset Untuk Bisnis dan Ekonomi, Jakarta, Erlangga

Luthans, Fred. 2011. Organizational Behavior: An Evidence-Based Approach. New York: McGraw-Hill.

Mangkunegara, Anwar Prabu, ( 2008 )Perilaku dan Budaya Organisasi,Bandung PT. RafikaAditama

Manulang, 2004,Manajemen Sumber Daya Manusia, Yogyakarta BPFE

Martoyo, Susilo 2000, Manajemen Sumber Daya Manusia (edisi3), Yogjakarta, BPFE

Mathis, Robert,L and Jackson, John, H ( 2006 ) Human Resource Manajement, Edisi.10 :Jakarta, Salemba empat

Nawawi, H. 2006. Kepemimpinan Mengefektifkan Organisasi. Cetakan Pertama. Gadjah Mada University Press. Yogyakarta

Rahmawati, Ike Kusdiyah( 2008 ) ManajemenSumberDayaManusiaEdisiPert ama, Yogyakarta, CV. Andi Offset

Richard, HunghesL, Robert, Ginnett C,Gordon, Curphy,J 2012, "Leadership memperkaya pelajaran dari pengalaman,Jakarta : SalembaHumanika.

Rivai,Veithzal,2005 Performance Appraisal, Jakarta, PT. Raja Grafindo Persada

-------------, 2010 Manajemen Sumber Daya Manusia Untuk Perusahaan Jakarta, PT. Raja Grafindo Persada

---------------, 2011, Manajemen Sumber Daya Manusia untuk Perusahaan: dari Teorike Praktik,Jakarta : RajaGrafindoPersada
Robbins, Stephen P .2003. Perilaku Organisasi. Jilid II. Jakarta : PT. Indeks KelompokGramedia

2006, Perilaku

Organisasi edisi 12, Jakarta Salemba Empat

2009, Organisation

Behaviour 13 Three Edition, USA : Pearson International Edition PrenticeHall

Sedarmayanti.2007. Sumber Daya Manusia dan Produktivitas Kerja. Bandung: CV MandarMaju.

-------------.2009. Sumber Daya Manusiadan Produktivitas Kerja. Bandung: CV MandarMaju.

Sekaran, Uma (2006). Metode Penelitian Bisnis 1. 4th Ed.TerjemahanKwab Men Yon.Bandung. Salemba Empat.

Siagian, Sondang P. 2003. Teori \& Praktek Kepemimpinan, Rineka Cipta, Jakarta

------ , 2013, Manajemen Sumber Daya Manusia, Bandung. BumiAksara,

Sinambela, Lijan Poltak. Dkk. 2011 .Reformasi Pelayanan Publik. Jakarta:Bumi Aksara

Situmorang, Ginting, 2008. Analisis Data Penelitian, Medan :USU Press,

Sudarmanto. 2009. Kinerja dan Pengembangan Kompetensi SDM (Teori, Dimensi Pengukuran dan Implementasi dalamO rganisasi). Yogyakarta : PustakaPelajar

Sugiyono, ( 2005 )MetodePenelitianAdministrasi, Bandung, Alfa Beta

------- ( 2008 )MetodePenelitianBisnis ( Pendekatan kuantitatif, kualitatif, $R \& D$ Bandung, Alfa Beta

Sutrisno, Edy 2014. Manajemen SumberDaya Manusia. CetakKe Enam. Jakarta. Pranada Media Group,

Wibowo . (2015) .Perilaku Dalam Organisasi. Edisi Kedua. Jakarta: PT Raja GrafindoPersada.

----------,(2016) Manajemen Kinerja .Jakarta,Edisi kelima, cetakan 10, Rajawali Pers. 